\title{
HERITAGE PERCEPTIONS: AN APPROACH FOR THE REVITALIZATION OF THE URBAN EXPERIENCES AND THE FRENCH CHECKBOARD IMAGE
}

DOI: 10.18485/arh_pt.2020.7.ch41

\author{
- Barbara Hiba \\ University of Pécs, Faculty of Engineering and Information \\ Technology, Breuer Marcell Doctoral School, Boszorkányu. 2, \\ H-7624 Pécs, Hungary, e-mail:barbara.hiba6@gmail.com

\section{_ Molnár Tamás \\ University of Pécs, Faculty of Engineering and Information Technology, Department of Visual Studies, Boszorkányu. 2, H-7624 Pécs, Hungary, e-mail: tmolnar@mik.pte.hu}

\begin{abstract}
Our human reality is the evidence for the historical and cultural transfers from our ancestor's legacies. Understanding authentic experiences in cities and architectural values carries the importance of its inheritance and meanings to our identities.

The urban scene conception and cultural landscapes in the city follow the identification of the receptive interactions of the physical and the perceptual dimensions of a defined space. The sequencing of the historical memories forms the relatable images and the observable variations of the built environment. People's perceptions and appreciation of their architectural and urban heritage become the indicator for generating a sense of place and symbolic character. The legacy of North African cities is related to the colonial past, where the design qualities produced during that period remain the focal interest of modern researches. By revisiting the urban scenery of the colonial times in Algeria, the French historical center's study in the city of Biskra aims to approach the potentials of the French-built heritage according to the improvement of the urban ambiance in the site and the patrimonial experiences of its users. The objective is to adapt the significant values and potential of the site, along with the requalification of its cultural landmarks and urban perspectives. The research methodology consists of investigating the right strategies towards a comprehensive and sustainable elaboration of the French models in Algeria.
\end{abstract}

KEYWORDS _ sustainable heritage, urban ambiance, cultural values, sense of place, social perception

\section{INTRODUCTION}

Throughout the years, the transmission of patrimonial and cultural values from generation to another was continuously connected to forming human experiences, therefore maintaining our ascendant heritages, legacies, and identities. The urban space with its physical platforms represents the container for the human events and historical memories, by producing multiple images and scenes that eventually indicates people's senses towards their cities and the qualities of their patrimony (Miguel. J, Tomás. L, Jesús. C, Carol. J, 2019 ). This dual exchange of values, both from material and immaterial dimensions of the urban space, is crucial to comprehending different design phe- 
nomena, from the primary architectural forms to the macro adaptations of the historical and urban environment.

According to the Burra charter 1979, the cultural significance of historical monuments and sites is defined according to different principles related to these past values and its various aspects, whether it is social, scientific, aesthetic, or even spiritual. ( The Burra charter 2013).

The Transition of cultural values was defined earlier in the Venice charter; the concept definition of the historical monument and the interest of its conservation and restoration was the main focus of the charter's articles. As followed, the ensemble of monuments and sites become an essential reflection of history, and only the preservation assures the respect of its authenticity. (The Venice charter 1964). The conservation of cultural heritage, including urban areas and historical centers, recommends the integration with the economic and social development planning in the cities. ( The Washington charter 1987).

The importance of the landmarks and monuments of authentic values is essential to analyzing the urban and the historical environment and assuring the understanding of cultural heritage perceptions. These landmarks; depending on its physical character, furthermore its archival qualities, become a visual guide in the cities, reflecting three main elements to creating its perceptual images: Identity, Structure, and signification ( Lynch.K, 1960). The different observable practices in the towns define urban scenes' production, followed by the appropriation of perceptual images and sensations while discovering the space. This latter constructs an essential ax to defining its characterizing features, according to particular perspectives, along with the conversion of various visual angles, related to the user's directions and positions in the site. ( Panerai. P. Demorgon. M, Depaule. J, 2009). The revaluation of the French heritage has been the subject of interest for many preservation projects that consider the safeguarding of the historical legacies regardless of the periods it reflects, but rather to the impact it has on the city today. The preservation of the local Medina in North African cities and the Grand Maghreb region has been lately complemented by actions of conserving the recent heritage of the colonial period, completing the preservation of the whole image of the city. The Agha khan award for the Tunis project of rehabilitation of the French façades near the old Medina of Tunis (Figure1) is one more affirmation for the necessity of this period's awareness. Most people, as a result, recognized this architecture's qualities by several rehabilitation actions on the urban façades and the restoration of essential monuments, calling for explicit insights on both the local and colonial cultural heritages. (Agha Khan award for architecture 2008-2010 cycle).
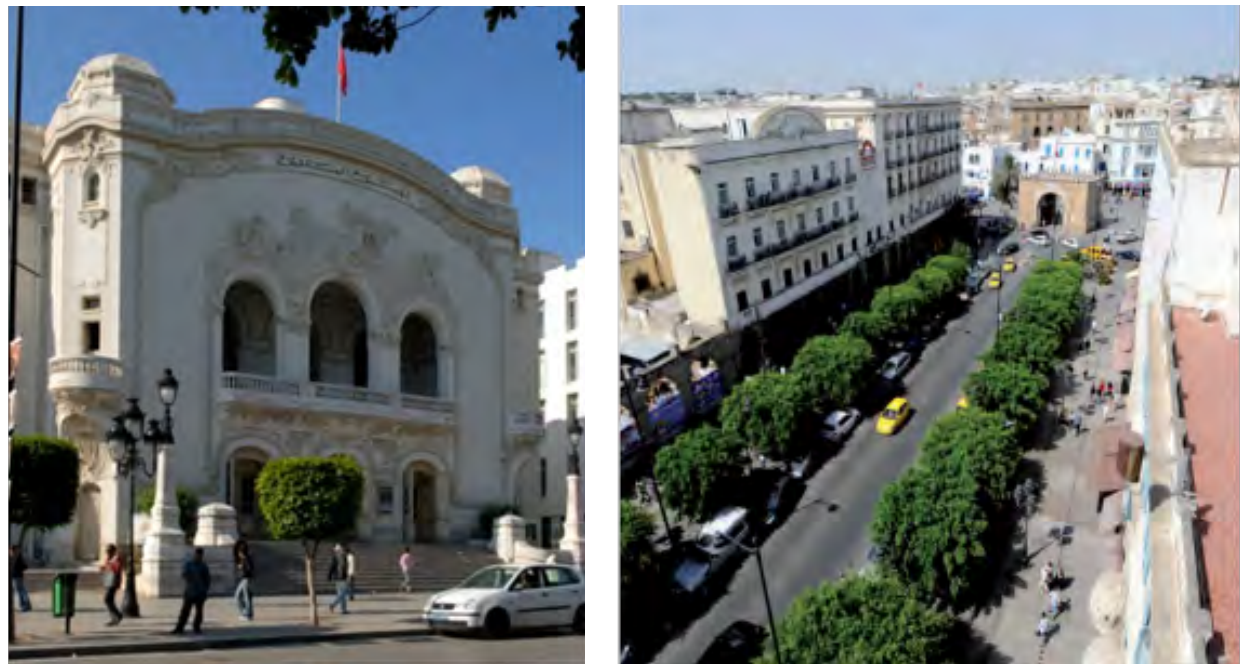

_ Figure 1: The Revitalisation of the Recent Heritage of Tunis, Tunisia. Source: The Agha Khan award for architecture 2008-2010 cycle 
In Algeria; The endorsement of the contemporary identities; encounters stereotypes of acceptance and appurtenance. For instance, the French heritage, although figures to be as one of the marking traces in the country's design features, is mainly held back by historical paradoxes, which essentially prevent further advancement in heritage conservation and protection strategies. (Barbara. $\mathrm{H}$, Molnár. T.2019). In Biskra, the French influence resumes in the design of many constructions that integrate into the local particularities of the region. However, it is the French checkboard planning that seems to be one of the city's outstanding structures. The historical center's regular morphology constructs a prominent checkboard organization, which creates a unique scenery when sighted with the rest of the local city. The meeting of two images, bounded by oriental and occidental concepts (Figure2), emphasizes the differences and supports the diversity and the cultural message of these contradicted forms. (Barbara, H. Molnár, PT.2019). The French ambiance created in the times of the Colonial period was characterized by specific values and urban qualities that reflect high interests in the Algerian cities, From the architectural styles to the urban planning. Nevertheless, in the light of urban development and the constant changing of modern life demands, The French historical center is unfortunately underrated and suffers from neglecting and disregard.

This research's main objectives are to create a comprehensive base to understand the impact of urban morphology on social perception. These aspects could build-up together towards the integration and understanding of the French heritage in the city's urban development and its local patrimony. The purpose is to revisit the original ambiance of the colonial checkboard, which approaches the human experience, stimulated by the visibility of its landmarks, roads, public spaces, etc. and their influence on the city's overall look. The analyses of the monuments and constructions' visual qualities are essential to approaching the aims of the study (Figure3). The appearance of the buildings and their general harmony is a crucial element to interpret their effect on the surrounding environment and vice versa and discloses a guideline towards the awareness on the historical site and its importance and certainly captures the sensibility to the image of the city today (Aidatul. F, Norhati. I, Sabarinah. S, Nurulhusna. Q. 2015).

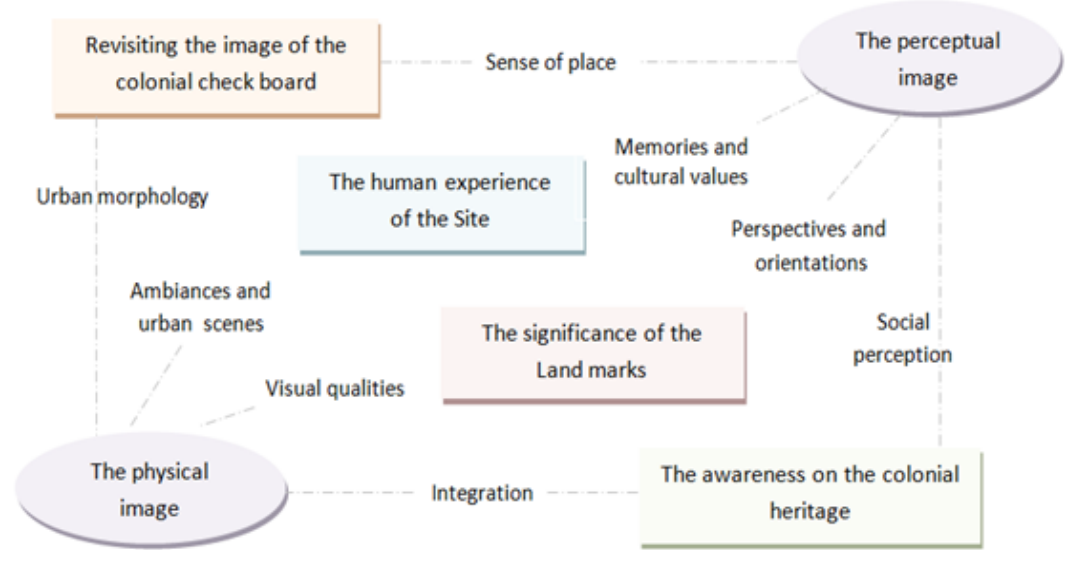

_ Figure 2: Theoretical framework, The regeneration of the image of the French check board in Biskra. Source: Author

\section{THE FRENCH CHECK BOARD OF BISKRA : TOWARDS THE IMAGE OF AN INTEGRATED HERITAGE}

The Algerian city Biskra, located north to the Grand Sahara, is considered the gate of the desert and characterized by its hot and dry climate. In French times, Biskra reflected the potential of strong tourism and formed a dynamic connection between territories. The city of the Oasis witnessed a 
shift in architectural and urban methods. From the modest use of local materials and integration with the typologies of the site; to the translation of a different French vocabulary that adapts regularity and modern forms to the design of the city, which comes around to create the significance of the site represented by architectural diversity and cultural engagement.

While first visiting the French center in Biskra( figure 3), a distinct regularity is introduced, visibly different from the rest of the city. The spatial and functional organization, together with the regular distribution of the equipment and its activities; facilitates the public use of the site. The colonial checkboard reflects the traces of a European city, which occurred in a specific time of history. The uncommon quarter's existence relates to the importance of architectural thinking under challenging conditions, considering the North Sahara region and its arid climate (Côte, M. 2005). The colonial checkboard mirrors the qualities and the importance of the French period, regardless of all past controversies, the urban and architectural components of the center comprise its significance and its value. The purpose is to analyze imagery of the site's landmarks, and the urban sensibility of the checkboard, setting the light on each value according to the scene it reflects with relation to its surrounding environment.
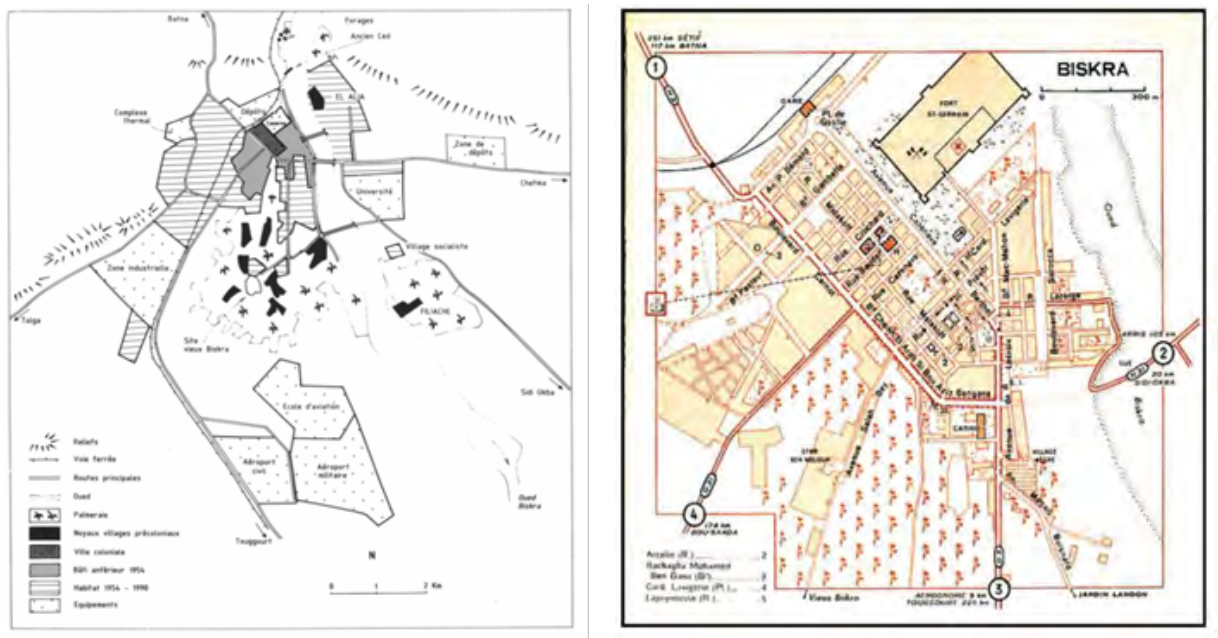

_ Figure 3: a. Biskra; the city of oasis. source: Côte, Marc. 1991, b. The colonial check board 1956.

Source: Guide vert michelin Edition 1956.

\section{THE SIGNIFICANCE OF THE LANDMARKS :}

The observation of the landmarks is an important aspect that contributes to creating the urban scenery and the planning of its layouts, with the needs of its users. The French monuments in the colonial checkboard, for instance, provide a variety of design styles and architectural concepts that has a significant impact on the rest of the cityscape, concerning beauty, harmony, and attraction, which makes it not only visible as landmarks, but also proportionally distinguishable on the macro scale of the city.

According to Kevin Lynch (Lynch, K.1960), the city's good image equals a good sense of orientation. It has a high impact on the legibility of the space and its visual signification, projecting this notion from the historical to the site's actual image. The construction of the original sequences of the colonial checkboard in the urban and historical timeline of the Biskra's old oasis undoubtedly contributes to forming the memories and nostalgias of this recent heritage and, as a result, the adaptation of a unique patrimonial identity.

The series of monuments conceived in the checkboard during different periods of the French ex- 
istence contribute to the shaping of the site's urban forms. With a variety of architectural styles, from Neoclassical to Neo-Moorish decorations and many other examples, the impressive buildings represent an affirmation to the importance of the oasis of the Ziban (old name of Biskra) and the ambition to promote a touristic essence to its local users and European visitors. The creation of the new European quarter was resumed by improving many buildings of different functions (Pizzaferri, P. 2011):

\section{THE RAILWAY STATION:}

The train station in the colonial checkboard is one of the orienting units in the site with a strategically positioned core, it serves as a historical landmark, but also as structuring. Located near the old military fort Saint Germain, the station of Biskra had the importance of relating the economical and the commercial roads between the north and the south of the country (Figure 5). The station's central position makes it a connection point while viewed from the principal boulevard of the site; the observer can capture the monument from a distance and multiple serial visions.
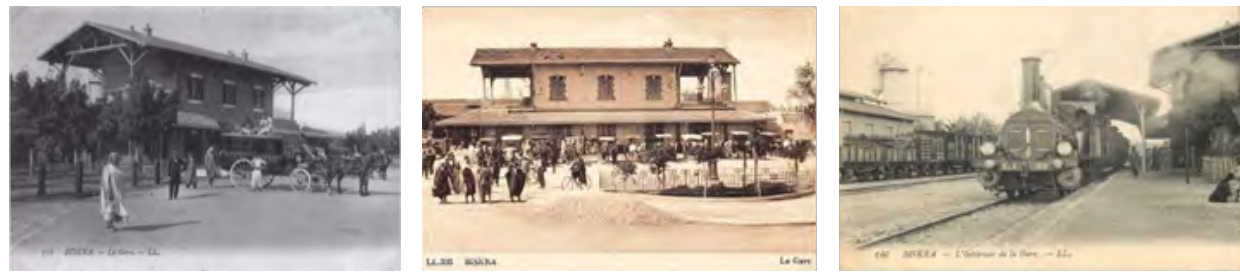

_ Figure 5: The railway station of Biskra. Source : Pizzaferri, Paul. 2011

\section{THE GRAND SAHARA HOTEL:}

The Hotel Sahara is one of the first-ever hotels in Algeria conceived with local and earthen materials, it is of the French neoclassical style and has a strong impact in the urban scene of the checkboard (Figure7), where it is highly visible from the Grand Boulevard and facing the public garden, the Hotel is a famous landmark and an essential entity which harmonizes perfectly with the composition of the urban façades and the rest of the French buildings.
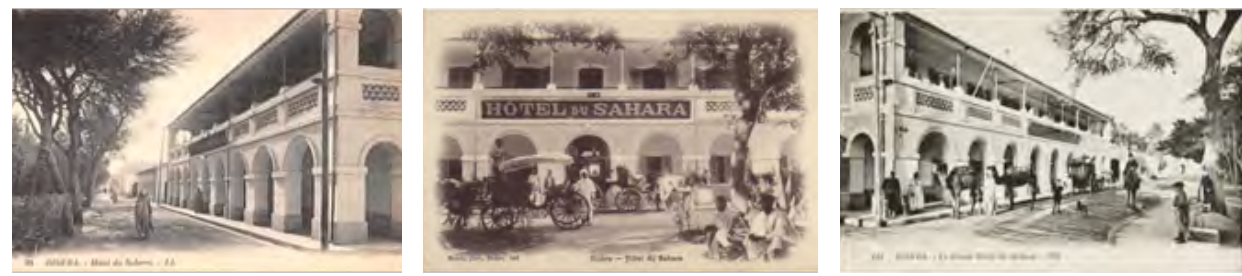

Figure 6: The Hotel of the Sahara. Source: https://www.judaicalgeria.com/; https://www.delcampe.net/; Pizzaferri, Paul. 2011

\section{THE EX CITY HALL:}

Not far away from the Sahara hotel, the Ex city hall and the actual municipality are essential and prestigious monuments in Biskra, which creates sharp images to the observant because of its outstanding design style and the visible monumentality to its overall scale (Figure8). The construction is strongly visible from various angles, presenting a strong singularity element and attraction that guides the visitor while navigating the colonial checkboard. 

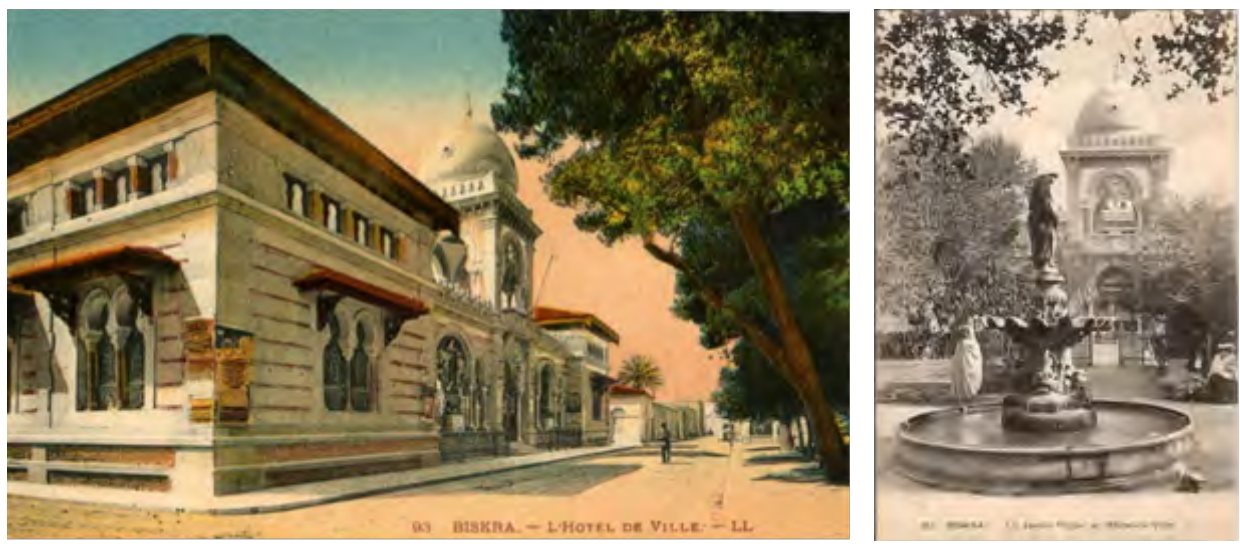

_ Figure 7: a. The city Hall, b. View on the water fountain facing the building. Source : https://www.geneanet.org/, Pizzaferri, Paul. 2011

\section{THE RODARI VILLAS:}

Private monument's importance is no less than the public ones, with a particular Neo Moorish style (Figure 8). The villas Rodari ( named after the French entrepreneur and architect Rodari) stand today in the site as the testimonies of the French engineers' creative achievements and surely stimulate original urban scenes that characterize the checkboard. The two houses have similar and singular design styles, making it easy to recognize in the site.

\section{THE PUBLIC GARDEN:}

The public garden in the colonial checkboard is probably the most fundamental structure when urbanely analyzing the site, with its peculiar disposition; it covers an important greenery level compared to the rest of the city, considering the arid conditions of the weather (Figure 8). As a public space, the 5th of July garden previously known as the " the Alleys garden," is equally essential to the built environment and monuments in the site, as it represents a familiar unit to most of the population in the city, and constructs a definite sequence in the image of the site, which makes it another punctual reference in the experience of the checkboard.
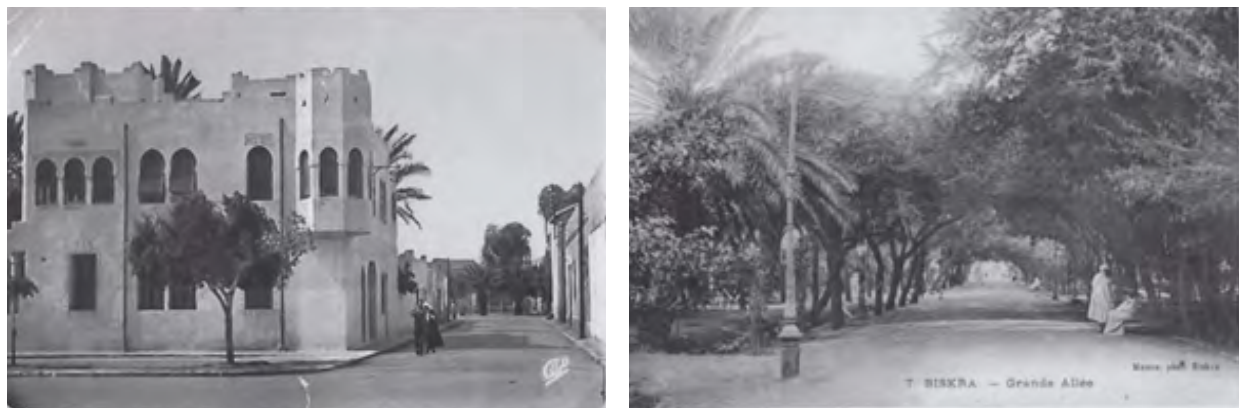

_ Figure 8: a. A Rodari villa of a neo Moorish style; b. The Grand Alley of the public garden. Source: Pizzaferri, Paul. 2011 


\section{CONCLUSIONS}

The requalification of these cultural landmarks is essential to evaluate the public image and the significance of the French Algerian platforms' urban scenery. Based on the patrimonial experiences, the site's potentials with its elements are emphasized upon the regeneration of its architectural and urban forms. The evaluation of the French monuments in the colonial checkboard of Biskra sets the foundation for recognizing each building's potentials, to be considered a significant landmark, that impacts the morphology and ambiance of the site. The qualities of the constructions are directly related to the different aspects and criteria that influence their appearance as referential points in the city: The localization; the form; the aesthetics; the harmony; and the singularity of the monuments, considered as the parameters that impact the visibility and the legibility of the landmarks and facilitates the construction and the perception of a unique image of the Recent heritage in the Algerian cities. The colonial checkboard faces multiple problems of disorientation on different levels, which are slowly affecting the quality of its landmarks and historical monuments. Mentioning the difficulties of accessibility; pollution; lack of parking spots; noise and structural pathologies diagnosed in a wide variety of buildings in the checkboard, as a consequence; the historical image is affected today by many factors that are causing the dysfunction and the imbalance of urban structure. According to its visual qualities, this analysis approach considers the French heritage, not necessarily to the historical events of its creation. As a result, it guides the research towards the importance of this legacy and the awareness of new heritage conservation methods and strategies to safeguarding the French monuments and sites in Algeria. It creates further perspectives for the adaptation of the social scale and the recognition of alterations and solutions for a sustainable integration with modern city planning.

\section{REFERENCES}

- Internet source: "Agha Khan award for architecture 2008-2010 cycle, "Revitalisation of the Recent Heritage of Tunis". Last Accessed March 25, 2020. https://www.akdn.org/architecture/project/revitalisation-recent-heritage-tunis.

_ Journal article: Aidatul Fadzlin Bakri, Norhati Ibrahim, Sabarinah Sh Ahmad, Nurulhusna Qamaruz Zaman. 2015. "Public Perception on the Cultural Significance of Heritage Buildings in Kuala Lumpur". Procedia Social and Behavioral Sciences 202 : $294-302$

- Journal article: Barbara Hiba, Molnár Tamás. 2019. "The French legacies in Algeria: The architecture of a shared identity, the case of the Kasbah; Algiers and the colonial check board; Biskra". Conference proceedings, the 6th international academic conference on places and technologies. Hungary; Pécs: 244252.

_ Journal article Barbara Hiba, Molnár Tamás. 2019. "Towards understanding the colonial heritage in Algeria: The case of the Sheridan Villa". Pollack Periodica, April, Vol. 14, Issue 1, pp. 223-234.

- Book: Côte, Marc. 2005. "The City and the desert : The Algerian low-Sahara". (in French : La ville et le désert: le bas-Sahara algérien). Karthala, Paris.

- Internet source: ICOMOS international council on monuments and sites. "International charter for the conservation and restoration of monuments and sites, the Venice charter 1964". Last Accessed June 25,2020. https://www.icomos.org/charters/venice_e.pdf.

- Internet source: ICOMOS international council on monuments and sites. "The Burra charter, the Australia ICOMOS Charter of cultural significance, 2013". Last Accessed June 25, 2020. https://australia. icomos.org/wp-content/uploads/The-Burra-Charter-2013-Adopted-31.10.2013.pdf.

- Internet source: ICOMOS international council on monuments and sites. "Charter for conservation of historic towns and urban areas, Washington charter 1987". Last Accessed June 25,2020. https://www. icomos.org/charters/towns_e.pdf.

- Book: Lynch, Kevin. 1960."The image of the city". Edited by Massachusetts Institute of Technology 
Cambridge, Massachusetts, and London, England. The M.I.T press.

- Journal article: Miguel Jesús Medina-Viruela, Tomás López-Guzmána, Jesús Claudio Pérez Gálveza, Carol Jara-Albab. 2019. " Emotional perception and tourist satisfaction in world heritage cities: The Renaissance monumental site of úbeda and baeza, Spain". Journal of Outdoor Recreation and Tourism no $27: 100226$.

_ Book: Pizzaferri, Paul. 2011 "Biskra, Queen of the Ziban and the south of Constantine.(in French:Biskra, reine des Ziban et du Sud constantinois).Vol. 2, Vol3, Jaques Gandinis Edition.

- Book: Philippe Panerai, Marcelle Demorgon, Jean-Charles Depaule. 2009. “Urban Analysis'. In French:

"Analyse urbaine". Edition Parenthèse. Marseille. 